\title{
Negative inotropic and chronotropic effects on the guinea pig atrium of extracts obtained from Averrhoa carambola L. leaves
}

C.M.L. Vasconcelos ${ }^{1,2}$, M.S. Araújo ${ }^{1}$, B.A. Silva ${ }^{2}$ and E.A. Conde-Garcia ${ }^{1}$

\author{
'Laboratório de Biofísica do Coração, Departamento de Fisiologia, \\ Centro de Ciências Biológicas e da Saúde, Universidade Federal de Sergipe, \\ Aracaju, SE, Brasil \\ 2Laboratório de Tecnologia Farmacêutica "Prof. Delby Fernandes de Medeiros", \\ Universidade Federal da Paraíba, João Pessoa, PB, Brasil
}

\section{Correspondence \\ E.A. Conde-Garcia \\ Laboratório de Biofísica do Coração Departamento de Fisiologia, CCBS \\ Universidade Federal de Sergipe \\ 49100-000 Aracaju, SE \\ Brasil \\ Fax: +55-79-246-3377 \\ E-mail: egarcia@ufs.br}

Research supported by ELETROBRAS (No. 23113.009351/03-67), FAP/SE (No. FAP-SE/FUNTEC/FNS/No. 01/ 2003), and CNPq

Received March 3, 2004 Accepted February 16, 2005

\begin{abstract}
It has been reported that star fruit can lead to a fatal outcome in uremic patients. The intoxication syndrome consists of hiccups, mental confusion, dizziness, and vomiting. On the other hand, folk medicine uses teas and infusions of carambola leaves to treat headache, vomiting, cough, insomnia, and diabetes. This motivated us to determine if Averrhoa carambola can act on the contractility and automaticity of the guinea pig heart. We measured the atrial isometric force in stimulated left atria and determined the chronotropic changes in spontaneously beating right atria. The carambola leaf extracts $(1.5 \mathrm{mg} / \mathrm{ml})$ abolished the contractile force in a concentration-dependent manner. Among the crude, methanolic, ethanolic, aqueous, and acetic extracts, the aqueous one was the most potent $\left(\mathrm{EC}_{50}=520 \pm 94 \mu \mathrm{g} / \mathrm{ml}\right.$; flavonoids and tannins are the main constituents; $\mathrm{Na}^{+}$and $\mathrm{K}^{+}$contents in $1.0 \mathrm{mg} /$ $\mathrm{ml}$ of aqueous extract were $0.12 \pm 0.016$ and $1.19 \pm 0.15 \mathrm{mM}$, respectively). The aqueous extract abolished the positive Bowditch staircase phenomenon and reduced the inotropic response to $\mathrm{CaCl}_{2}$ (0.17-8.22 mM), events that are dependent on the cellular $\mathrm{Ca}^{2+}$ inward current. The adrenergic, muscarinic or opioid membrane receptors do not seem to participate in the mechanism of action of the cardioactive substance(s). In spontaneously beating atria, the aqueous extract promoted a negative chronotropic effect that was antagonized by $0.1 \mu \mathrm{M}$ isoproterenol bitartrate. With this agonist, the $\mathrm{EC}_{50}$ of the aqueous extract increased from $133 \pm 58$ to $650 \pm 100$ $\mu \mathrm{g} / \mathrm{ml}$. These data regarding the effect of $A$. carambola on guinea pig atrial contractility and automaticity indicate an L-type $\mathrm{Ca}^{2+}$ channel blockade.
\end{abstract}

\section{Introduction}

Averrhoa carambola L. (star fruit, 'carambola' in Brazil) is a plant of the
Key words

- Averrhoa carambola L.

- Star fruit

- Inotropism

- Chronotropism

- Guinea pig atrium

- $\mathrm{Ca}^{2+}$ channel blockade .......................
Oxalidaceae family. Originating from Asia, it can be found widely spread in tropical countries. In Brazilian folk medicine, its fruit, juice or tea prepared from its leaves, has been used 
for treating headache, vomiting, cough, insomnia, hypertension, and diabetes (1-5). The literature reports that uremic patients develop severe and acute intoxication after eating carambola or drinking its juice, with intractable hiccups, sudden onset of limb numbness, muscle weakness, consciousness disturbance, and seizure $(6,7)$. These neurological events can be treated only by submitting the patients to hemodialysis. In spite of this therapeutic effort, many cases show a poor outcome which result in death (8-10). A water-soluble neurotoxin was isolated from star fruit (11). This protein induced convulsion in rats by acting on Lglutamate release, as demonstrated in synaptosomes prepared from the rat cerebral cortex (8). These clinical and experimental effects motivated us to test some of the $A$. carambola extracts on the mammalian heart because folk medicine extensively uses teas and infusions obtained from carambola leaves.

The objective of the present study was to investigate the myocardial effects produced by $A$. carambola leaf extracts on left atrium contractility and automaticity of spontaneously beating isolated guinea pig right atria.

\section{Material and Methods}

\section{Extract preparation}

Averrhoa carambola leaves were collected on the campus of the Federal University of Sergipe (Brazil) from healthy and agrotoxicfree plants. The botanical identification was performed by comparing the vegetal parts with those deposited in the Herbarium of the Federal University of Pernambuco, Brazil (Voucher No. 24,720). The crude extract was obtained by macerating dry leaves in a water:ethanol mixture $(6: 4, v / v)$ for 10 days at $27 \pm 3^{\circ} \mathrm{C}$. The solvents were then filtered and evaporated in a rotary evaporator (Tecnal TE 210, Piracicaba, SP, Brazil) and a crude extract was obtained. Several extracts were also obtained by submitting another set of dry leaves to a hot extraction with hexane, chloroform, acetone, ethanol, methanol, water, and acetic acid using a Soxhlet apparatus. Each extract was concentrated in a rotary evaporator and stored at $27 \pm 3^{\circ} \mathrm{C}$ in a dry environment. The water-insoluble residue of each extract was determined to permit correct adjustment of the extract concentration in the organ bath.

\section{Phytochemistry screening}

The phytochemistry screening was performed on the $A$. carambola aqueous extract (AEx) according to the techniques proposed by Domínguez (12).

\section{Measurement of $\mathrm{Na}^{+}$and $\mathrm{K}^{+}$}

The $\mathrm{Na}^{+}$and $\mathrm{K}^{+}$contents of the AEx were determined by flame photometry (Instituto de Tecnologia e Pesquisa de Sergipe, Governo do Estado de Sergipe, Aracaju, SE, Brazil).

\section{Aqueous extract fractionation}

Five grams of the AEx was loaded on a $4 \mathrm{x}$ $80 \mathrm{~cm}$ silica gel 60 chromatographic column (Sigma-Aldrich, St. Louis, MO, USA). The column was eluted with a mixture of methanol and water with increasing polarity (100:0, 95:5, 90:10, 80:20, 50:50, and 0:100, v/v).

\section{Inotropic effect of Averrhoa carambola}

The contractile force of the extract was evaluated in the guinea pig isolated left atria. Animals of both sexes (300-500 g) were sacrificed by a blow applied to the base of the skull. The heart was removed and the left atrium was mounted in an organ chamber where it was bathed with modified Tyrode solution $(5 \mathrm{ml})$ of the following composition: $137 \mathrm{mM} \mathrm{NaCl}, 5.0 \mathrm{mM} \mathrm{KCl}, 0.5 \mathrm{mM} \mathrm{MgCl}_{2}$, $12 \mathrm{mM} \mathrm{NaHCO} 3,1.8 \mathrm{mM} \mathrm{CaCl}_{2}, 6.0 \mathrm{mM}$ glucose, $1.8 \mathrm{mM} \mathrm{NaH}_{2} \mathrm{PO}_{4}$. The Tyrode solution was maintained at $27 \pm 0.1^{\circ} \mathrm{C}$ with a circulating water bath (IBBL model FN 2000, 
Itu, SP, Brasil and HAAKE FJ, BW 76227, Karlsruhe, Germany) and oxygenated with a gas mixture consisting of $95 \% \mathrm{O}_{2}$ and $5 \%$ $\mathrm{CO}_{2}$. The atria were stretched to $10 \mathrm{mN}$ and submitted to field stimulation of $2 \mathrm{~Hz}$. The stimulation pulses ( $400 \mathrm{~V}$ and $0.5 \mathrm{~ms}$ ) were provided by a Digitimer 3072 Stimulator, which was controlled by a Digitimer D4030 Programmer (Welwyn, Garden City, Hertfordshire, England). The atrial force was recorded with an isometric force transducer (HP FTA 10-1 Sunborn, Chicago, IL, USA) coupled to a thermal paper polygraph (HP8805B, HP7754A/B). The electrical signals were also stored in a computer to be processed off-line (DATAQ DI400, DI 205, WINDAQ PRO Acquisition, Windaq EX Calculate, Akron, OH, USA).

To analyze the atrial contractile force data stored in the computer, fifty successive contractions were selected from each experimental procedure (control, test, and washout) and their parameters were determined and averaged with the EG1v1 software (Conde-Garcia, Patent deposit No. 00051104 Instituto Nacional de Propriedade Industrial - INPI, Ministério do Desenvolvimento, Indústria e Comércio Exterior, Brasília, DF, Brasil, also deposited at the Cartório do $10^{\circ}$ Ofício, Títulos e Documentos e Pessoas Jurídicas, Aracaju, SE, Brazil).

Determination of the relative potencies of the extracts

To determine the $\mathrm{EC}_{50}$ (concentration needed to produce $50 \%$ of the maximum effect) of each $A$. carambola extract, the force amplitudes obtained with different extract concentration in the organ bath were fitted by curves calculated by the HillLangmuir equation:

$$
\mathrm{E}=\frac{\mathrm{E}_{\max }\left(\frac{\mathrm{C}}{\mathrm{EC}_{50}}\right)^{\mathrm{n}}}{1+\left(\frac{\mathrm{C}}{\mathrm{EC}_{50}}\right)^{\mathrm{n}}}
$$

where: $\mathrm{E}=$ effect of the extract on the contractile force amplitude; $\mathrm{E}_{\max }=$ maximum effect of the extract on the contractile force amplitude; $\mathrm{C}=$ extract concentration in the organ bath; $\mathrm{EC}_{50}=$ extract concentration needed to produce $50 \%$ of the maximum effect; $\mathrm{n}=$ Hill constant.

\section{Averrhoa carambola vs membrane receptors}

To determine whether opioid, muscarinic or $\beta$-adrenergic membrane receptors could be involved in the mechanism of action of $A$. carambola, the inotropic effect produced by the AEx was tested in artificially paced guinea pig left atria both in a control situation and after blocking each one of the specific membrane receptor. For this procedure, the following drugs were added to the organ bath: $1.5 \mu \mathrm{M}$ atropine sulfate, $0.7 \mu \mathrm{M}$ propranolol hydrochloride, or $120 \mu \mathrm{M}$ naloxone hydrochloride.

\section{Chronotropic effect of Averrhoa carambola}

To test the effect of the extract on the atrial pacemaker activity, some experiments were carried out in spontaneously beating guinea pig right atria. The biological preparations remained immersed in a modified Tyrode solution (13). The preparation, previously stretched to a resting tension of $5 \mathrm{mN}$, was maintained at $27 \pm 0.1^{\circ} \mathrm{C}$. The atrial rate was determined by measuring the interval between successive contractions. For this procedure, fifty contractile force curves were processed with the EG1v1 software. Concentration-response curves for the $\mathrm{A}$. $\mathrm{ca}$ rambola AEx (0.005 to $1.6 \mathrm{mg} / \mathrm{ml})$ were obtained in a control situation or after adding $0.1 \mu \mathrm{M}$ isoproterenol bitartrate to the bath.

\section{Averrhoa carambola vs inward $\mathrm{Ca}^{2+}$ current}

The cellular inward $\mathrm{Ca}^{2+}$ current was studied using the Nayler and Merrillees protocol (14) applied to guinea pigs reserpinized 
( $5 \mathrm{mg} / \mathrm{kg}$, ip) $24 \mathrm{~h}$ before the experiment. This experimental protocol is based on the Bowditch positive staircase, a phenomenon that is dependent on the cellular inward $\mathrm{Ca}^{2+}$ current. The experiments were carried out in five successive phases: 1) the left atrium was maintained under a low frequency of stimulation $(0.2 \mathrm{~Hz}$, control); 2) the stimulation rate was abruptly increased to $0.33,0.66$, $1.0,1.33$, or $1.66 \mathrm{~Hz}$ for $50 \mathrm{~s}$; 3) the stimulation was interrupted for $40 \mathrm{~s}$; finally, $5)$ the control rate $(0.2 \mathrm{~Hz})$ was reinitiated. This experimental sequence was followed before and after adding the A. carambola AEx to the organ bath.

In addition to the Nayler and Merrillees protocol, concentration-response curves obtained by progressively adding $\mathrm{CaCl}_{2}$ to the organ bath were used to study calcium entry in cardiac cells. The experiments were carried out in guinea pig left atria previously stretched to a resting tension of $4.9 \mathrm{mN}$, maintained at $27^{\circ} \mathrm{C}$, and under electrical stimulation of 1.5 $\mathrm{Hz}$. The calcium concentration in the Tyrode solution was increased to the following values: $0.17,0.34,0.685,1.37,2.05,2.74,4.11,5.48$, 6.85 , and $8.22 \mathrm{mM}$ and the atrial force was recorded as described above.

\section{Determination of oxalic acid}

The Hodgkinson colorimetric method modified by Rassi and Damas (15) was used to determine the oxalic acid content in 1.0 $\mathrm{mg} / \mathrm{ml}$ AEx of carambola.

Figure 1. Negative inotropic effect promoted by the crude extract of Averrhoa carambola on the guinea pig left atrium. The extract was cumulatively added to the organ bath and the effect was concentration-dependent. The atrium was paced at $2 \mathrm{~Hz}$ with pulses of $400 \mathrm{~V}$ and $0.5 \mathrm{~ms}$ $\left(27 \pm 0.1^{\circ} \mathrm{C}\right)$. Similar results were observed in 14 trials carried out in 8 atria.

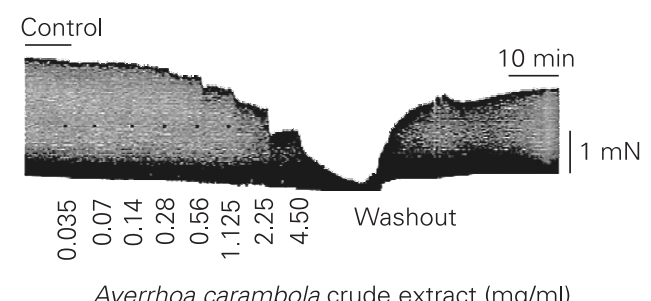

Averrhoa carambola crude extract $(\mathrm{mg} / \mathrm{ml})$

\section{Statistical analysis}

Data are reported as means \pm SEM. The Student $t$-test for unpaired data was used to determine differences between means. The results were considered to be statistically different when $P$ was less than 0.05 (Statistica for Windows, Tulsa, OK, USA).

\section{Drugs}

The following drugs were used: $1.5 \mu \mathrm{M}$ atropine sulfate, $0.3 \mu \mathrm{M}$ acetylcholine chloride, $0.7 \mu \mathrm{M}$ propranolol hydrochloride, 1 $\mu \mathrm{M}$ and $0.1 \mu \mathrm{M}$ isoproterenol bitartrate, 120 $\mu \mathrm{M}$ naloxone hydrochloride, and $5 \mathrm{mg} / \mathrm{kg}$ reserpine. Drugs were purchased from Sigma-Aldrich, except naloxone (Rhodia Farma Ltda., São Paulo, SP, Brazil) and reserpine (kindly supplied by Laboratório Gross S.A., Rio de Janeiro, RJ, Brazil).

\section{Results}

The yield of each $A$. carambola extract (g/100 g of dry leaves) was: crude (15.0), hexane (2.36), chloroform (1.75), acetone (5.16), ethanol (13.4), methanol (2.92), aqueous (7.8), and acetic acid (18).

Figure 1 shows the negative inotropic effect produced by the $A$. carambola crude extract on the guinea pig left atrium. The effect, clearly dependent on extract concentration, disappeared when A. carambola was removed from the bath (washout).

To calculate the relative potency of the $A$. carambola extracts, the atrial force-concentration data were fitted with Hill-Langmuir curves. The results showed that the AEx was the most potent $\left(\mathrm{EC}_{50}=520 \pm 94 \mu \mathrm{g} / \mathrm{ml}, \mathrm{N}=\right.$ 4, 10 trials, Hill constant $=3, \mathrm{P}<0.001$ when compared to the ethanol, methanol, acetic acid, or crude extract). The following results were obtained for the remaining extracts: etha$\operatorname{nol}\left(\mathrm{EC}_{50}=700 \pm 65 \mu \mathrm{g} / \mathrm{ml}, \mathrm{N}=3\right.$, Hill constant $=2)$, methanol $\left(\mathrm{EC}_{50}=1200 \pm 171 \mu \mathrm{g} / \mathrm{ml}, \mathrm{N}\right.$ $=3$, Hill constant $=3)$, acetic $\operatorname{acid}\left(\mathrm{EC}_{50}=1400\right.$ 
$\pm 285 \mu \mathrm{g} / \mathrm{ml}, \mathrm{N}=3$, Hill constant $=2$ ), and crude extract $\left(\mathrm{EC}_{50}=1400 \pm 283 \mu \mathrm{g} / \mathrm{ml}, \mathrm{N}=\right.$ 8,14 trials, Hill constant $=2$ ). Figure 2 depicts the concentration-effect curves for the aqueous and crude extract.

The phytochemical screening of the AEx revealed the presence of the following components: 1) saponin [foam (-)]; 2) alkaloid [Bouchardat (-), Mayer (-), Dragendorff (-), tungstosilicic acid (-)]; 3) steroid [acetic anhydride plus sulfuric acid $(+)]$; 4) tannin [gelatin $(+), \mathrm{FeCl}_{3}(+++)$ ], and 5) flavonoid [magnesium tape $(++)$, fluorescence $(+++)$ ]. The oxalic acid concentration of this extract was only $21 \mu \mathrm{g} / \mathrm{ml}$.

Flame photometry revealed that the $\mathrm{Na}^{+}$ and $\mathrm{K}^{+}$contents of the AEx were $0.12 \pm$ $0.016 \mathrm{mM}$ and $1.19 \pm 0.15 \mathrm{mM}$, respectively. To determine whether this $\mathrm{K}^{+}$concentration could be responsible for the negative inotropic effect of AEx, some experiments were carried out by progressively increasing the $\mathrm{K}^{+}$concentration in the bath from 5 to 7 $\mathrm{mM}$ and the atrial force was measured. This concentration range was chosen because the maximum depressant effect of AEx was reached when it was concentrated at $1.5 \mathrm{mg} /$ $\mathrm{ml}$ in the organ chamber. This concentration increased the potassium content of Tyrode solution from 5 to $6.78 \mathrm{mM}$. In the presence of $7 \mathrm{mM} \mathrm{K}^{+}$, the atrial force amplitude decreased by only $10 \%$. This change is not compatible with the negative inotropic effect of the AEx because when the extract was used at $1.5 \mathrm{mg} / \mathrm{ml}$ - which is equivalent to a total $\mathrm{K}^{+}$concentration of $6.78 \mathrm{mM}$ in the bath solution - the atrial force decreased by more than $99 \%$ of its control value.

To determine the possible involvement of membrane receptors in the negative inotropic effect of $A$. carambola, experiments were performed by using a fraction (FAEx) obtained by eluting the AEx with a $1: 1$ methanol:water (v/v) mixture through a silica gel 60 column. This FAEx was more potent than the carambola $\mathrm{AEx}\left(\mathrm{EC}_{50}=140 \pm 7 \mu \mathrm{g} /\right.$ $\mathrm{ml}, \mathrm{N}=3,5$ trials, $\mathrm{P}<0.001)$, suggesting that the active principle was concentrated in it. The inotropic effect of FAEx was determined both in the control solution and after blocking membrane receptors. Since the contractile effect remained unchanged after the receptor blockade (Figure 3), we assume

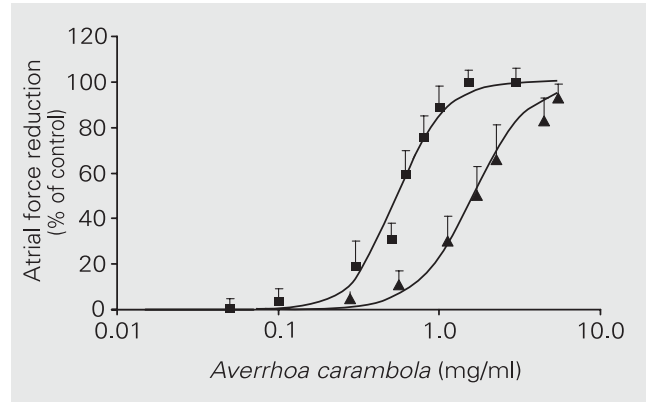

Figure 2. Hill-Langmuir curves constructed to determine the relative potency of aqueous (squares) and crude (triangles) Averrhoa carambola extracts. The extracts were aqueous $\left(\mathrm{EC}_{50}=520 \pm 94 \mu \mathrm{g} / \mathrm{ml}\right.$, Hill constant $=3, \mathrm{~N}=4$ atria, 10 trials) and crude $\left(\mathrm{EC}_{50}=1400 \pm\right.$ $283 \mu \mathrm{g} / \mathrm{ml}$, Hill constant $=2, \mathrm{~N}$ $=8$ atria, 14 trials). The experiments were carried out in guinea pig left atria (stimuli: $2 \mathrm{~Hz}$, $400 \mathrm{~V}, 0.5 \mathrm{~ms} ; 27 \pm 0.1^{\circ} \mathrm{C}$, resting tension: $10 \mathrm{mN}$ ). The $\mathrm{EC}_{50}$ were significantly different $(\mathrm{P}<$ 0.001 , paired Student $t$-test).

A

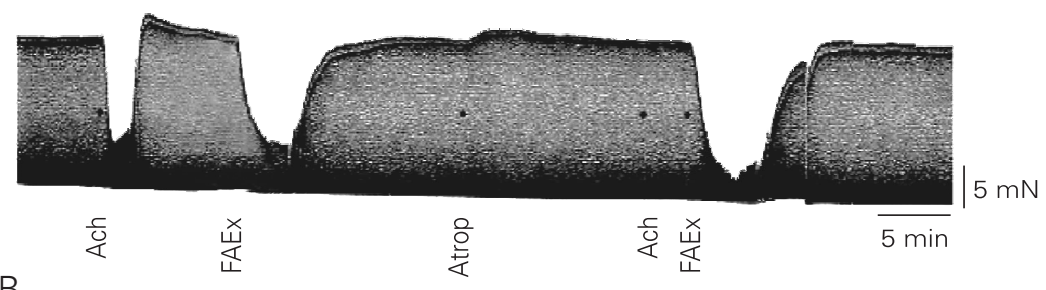

$B$

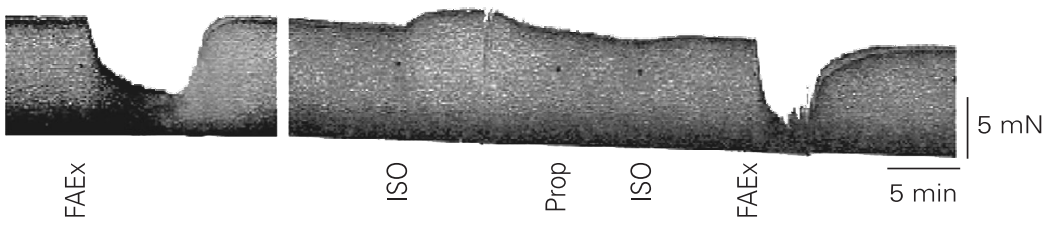

C

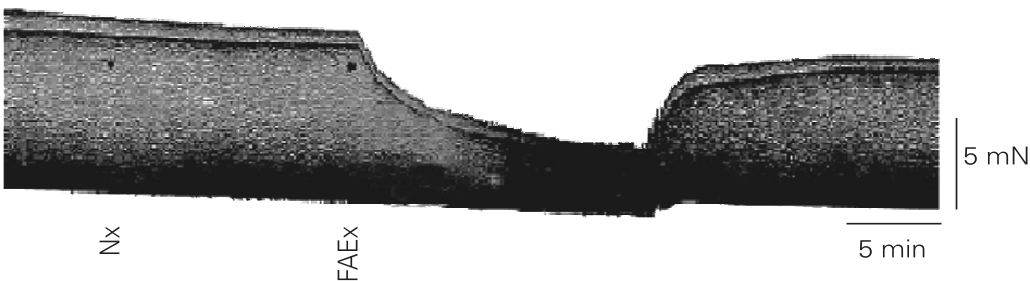

Figure 3. A, Atropine sulfate (Atrop, $1.5 \mu \mathrm{M})$; $B$, propranolol hydrochloride (Prop, $0.7 \mu \mathrm{M})$, or $C$, naloxone hydrochloride $(\mathrm{Nx}, 120 \mu \mathrm{M})$, although blocking the muscarinic, ß-adrenergic and opioid receptors, respectively, did not modify the depressor effect produced by the Averrhoa carambola aqueous fraction (FAEx, $0.6 \mathrm{mg} / \mathrm{ml}$ ), suggesting that none of them participate in the mechanism of action of this extract on the guinea pig atrium. ISO: isoproterenol bitartrate $(1 \mu \mathrm{M})$; Ach = acetylcholine chloride $\left(0.3 \mu \mathrm{M} ; 27 \pm 0.1^{\circ} \mathrm{C}\right.$, stimuli: $2 \mathrm{~Hz}, 400 \mathrm{~V}, 0.5 \mathrm{~ms}$ ). 


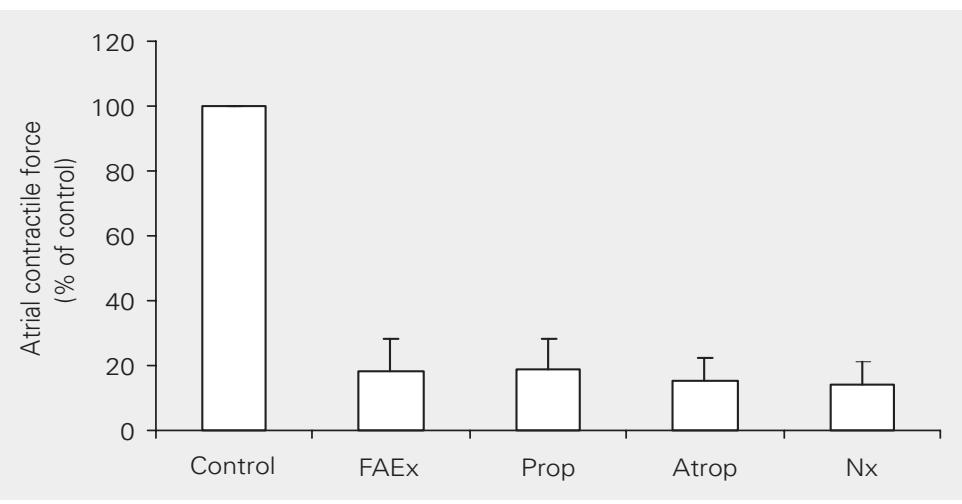

Figure 4. Atrial force reduction of $82 \%$ induced by $0.6 \mathrm{mg} / \mathrm{ml}$ Averrhoa carambola aqueous fraction (FAEx). The experiments were carried out in the guinea pig left atrium using at least 3 atria to test each of the receptors $\left(27 \pm 0.1^{\circ} \mathrm{C}\right.$, stimuli: $2 \mathrm{~Hz}$, $400 \mathrm{~V}, 0.5 \mathrm{~ms}$ ). The blockade of adrenergic, cholinergic or opioid membrane receptors promoted by propranolol hydrochloride (Prop, $0.7 \mu \mathrm{M}$ ), atropine sulfate (Atrop, $1.5 \mu \mathrm{M})$ or naloxone hydrochloride $(\mathrm{Nx}, 120 \mu \mathrm{M})$ did not modify $(\mathrm{P}>0.05$, unpaired Student $t$-test) the depressor effect of the FAEx on myocardial contractility.

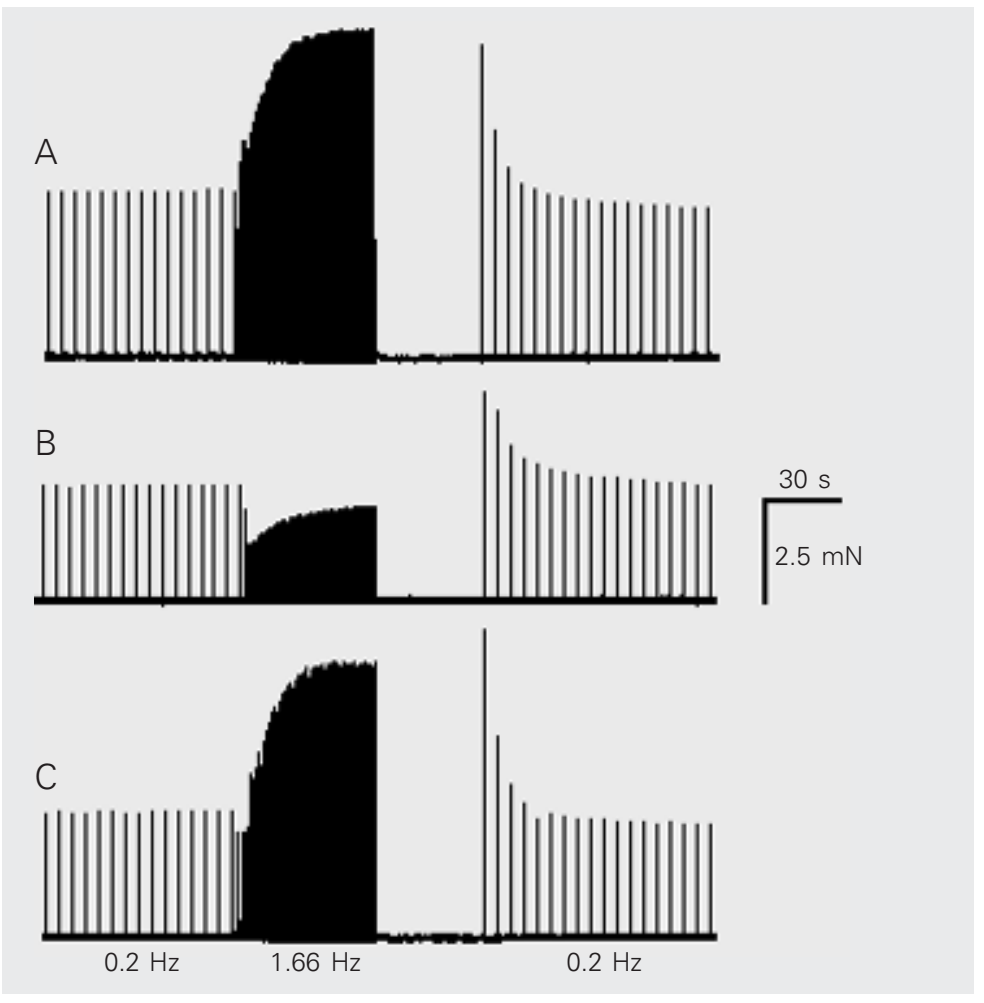

Figure 5. Effect of the Averrhoa carambola aqueous extract (AEx) on the membrane calcium inward current studied by the Bowditch positive staircase phenomenon which was obtained by increasing the atrial rate from 0.2 to $1.66 \mathrm{~Hz}$. A, Atrial contractile force in control solution. During the stimulus overdrive the atrial force increased from 5.25 to $9.5 \mathrm{mN}$ (80.9\%). B, Atrium submitted to $1.0 \mathrm{mg} / \mathrm{ml}$ AEx. In this case, during overdrive, the atrial force declined from $3.7 \mathrm{mN}$ to $3.2 \mathrm{mN}$ $(13.5 \%)$. C, Atrial force behavior during washout. In this experimental phase, the atrial force increased from 4.1 to $8 \mathrm{mN}(95.1 \%)$ when the preparation was in overdrive. The experiment was carried out at $27 \pm 0.1^{\circ} \mathrm{C}$ (stimuli: 0.2 or $1.66 \mathrm{~Hz}$, $400 \mathrm{~V}, 0.5 \mathrm{~ms})$. that none of them mediated the negative response promoted by FAEx (Figure 4, N = 3 atria).

Figure 5 depicts the Bowditch phenomenon obtained with the Nayler and Merrillees protocol. In this case, the stimulation rates were: $0.2 \mathrm{~Hz}$ in the control, $1.66 \mathrm{~Hz}$ during the overdrive, and $0.2 \mathrm{~Hz}$ after the stimulation pause. The upper panel shows that during the overdrive the atrial force increased from 5.25 to $9.5 \mathrm{mN}$ (atrial force overshoot equal to $80.9 \%$ ). The middle panel shows the result obtained after adding $1.0 \mathrm{mg} / \mathrm{ml}$ of AEx to the bath. Note that, during overdrive, instead of an atrial force overshoot, a slight decrease in atrial force $(13.5 \%)$ from 3.7 to $3.2 \mathrm{mN}$ was observed. This effect, however, disappeared during washout (lower panel) and the Bowditch phenomenon was restored to its control behavior (from 4.1 to $8 \mathrm{mN}$, $95.1 \%$ of the control atrial force).

Figure 6 shows that, insofar as the overdrive rate was increased from 0.2 to $1.66 \mathrm{~Hz}$ $\left(\mathrm{N}=3\right.$ hearts, $\left.27 \pm 0.1^{\circ} \mathrm{C}\right)$, the atrial force overshoot progressively increased to $84 \%$ (control solution). When the overdrive rate was increased with AEx $(1.0 \mathrm{mg} / \mathrm{ml})$ in the bath, the atrial force, instead of increasing, decreased by about $16 \%$. Nevertheless, this effect was not dependent on the stimulation rate applied. These effects rapidly disappeared during washout and the preparations recovered their control contractile ability.

The inotropic effect induced by cumulative addition of $\mathrm{CaCl}_{2}(0.17$ to $8.22 \mathrm{mM})$ to the organ bath fluid is depicted in Figure 7. AEx caused both a progressive shift of the log concentration-response curve for $\mathrm{CaCl}_{2}$ to the right and a reduction of the maximum effect of the AEx $(2.0 \mathrm{mg} / \mathrm{ml})$ from 100 to 64 $\pm 8 \%$. In the control solution the $\mathrm{EC}_{50}$ of $\mathrm{CaCl}_{2}$ was $1.7 \pm 0.3 \mathrm{mM}$ but with $\mathrm{AEx}$ at concentrations of 1.2 and $2.0 \mathrm{mg} / \mathrm{ml}$, the $\mathrm{EC}_{50}$ changed to $4.2 \pm 0.4$ and $7.2 \pm 0.9 \mathrm{mM}$, respectively $(\mathrm{P}<0.05)$.

In the spontaneously beating atria, AEx promoted a negative chronotropic effect that 
was dependent on the extract concentration (Figure 8). At the maximum effect, which was obtained with a concentration of $1.6 \mathrm{mg} /$ $\mathrm{ml}$, the spontaneous atrial rate decreased by about $99 \%(\mathrm{P}<0.001, \mathrm{~N}=4$ atria, 5 trials $)$, leading some preparation to complete asystole. By adding isoproterenol bitartrate (0.1 $\mu \mathrm{M})$ to the organ bath, the concentrationeffect curve was shifted to the right, its $\mathrm{EC}_{50}$ increased from $133 \pm 58$ to $650 \pm 100 \mu \mathrm{g} / \mathrm{ml}$ $(\mathrm{P}<0.001, \mathrm{~N}=4$ atria $)$, and the relative efficacy decreased from 100 to $33.4 \pm 14 \%$ $(\mathrm{P}<0.001, \mathrm{~N}=4$ atria $)$.
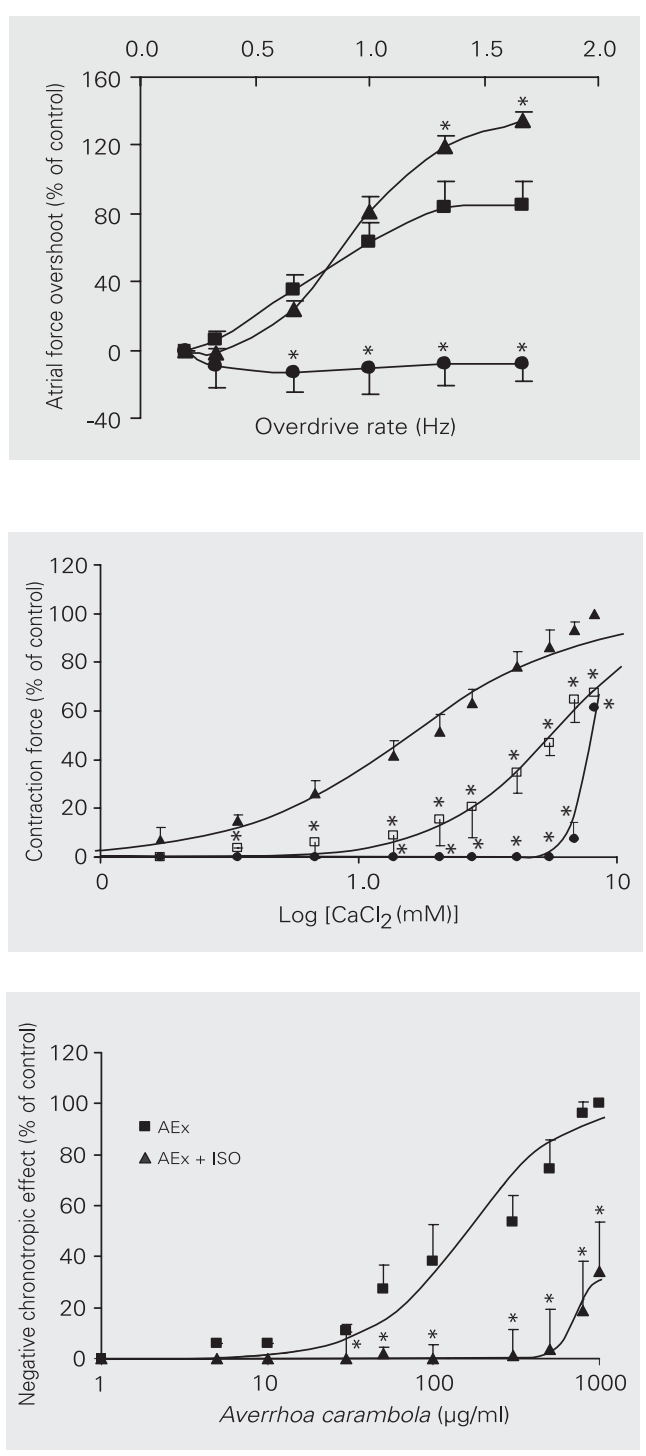

\section{Discussion}

The results presented here demonstrated that $A$. carambola promotes a decrease in cardiac contractility in the guinea-pig atria. This effect was observed when using the crude, ethanol, methanol, or acetic acid extracts. The AEx was the most potent, indicating that active substance(s) is(are) water soluble and polar. Despite the well-defined negative effect of $A$. carambola on myocardial contractility, the atrial force promptly recovered to control values during washout.

Figure 6. Effects of stimulation rate on the amount of force over the control one (Bowditch phenomenon). Squares: control curve; circles: test curve obtained with $1.0 \mathrm{mg} / \mathrm{ml}$ Averrhoa carambola aqueous extract; triangles: washout curve. The experiments were carried out in guinea pig left atria ( $N=4$ atria, $\left.27 \pm 0.1^{\circ} \mathrm{C}\right) .{ }^{*} \mathrm{P}<$ 0.001 compared to the control curve (paired Student $t$ test)

Figure 7. Inhibition by the aqueous extract of Averrhoa carambola of the positive inotropic effect induced by increasing $\mathrm{CaCl}_{2}$ concentrations in the left driven atria. $\mathrm{CaCl}_{2}$ was added cumulatively to the organ bath. Points are means \pm SD of 6 atria (14 assays). Triangles: control; squares: $1.2 \mathrm{mg} / \mathrm{ml}$ aqueous extract; circles: $2.0 \mathrm{mg} / \mathrm{ml}$ aqueous extract. Concentration-response curves were significantly shifted to the right $\left({ }^{*} \mathrm{P}<\right.$ 0.05 , paired Student $t$-test) and the relative efficacy decreased from 100 to $64 \pm 8 \%\left(27 \pm 0.1^{\circ} \mathrm{C}, 1.5 \mathrm{~Hz}\right)$.

Figure 8. Concentration-response curves for the negative chronotropic effect promoted by the aqueous extract (AEx) of Averrhoa carambola in the absence $\left(E C_{50}=133 \pm 58 \mu \mathrm{g} / \mathrm{ml}\right)$ or in the presence of $0.1 \mu \mathrm{M}$ isoproterenol (ISO, $\mathrm{EC}_{50}=650 \pm 100 \mu \mathrm{g} / \mathrm{ml}$ ). With ISO, the concentration-response curve was shifted to the right $\left({ }^{*} P<0.01\right.$, paired Student $t$-test $\left.)\right)$ and the relative efficacy decreased from 100 to $33.4 \pm 14 \%$, P $<0.01\left(27 \pm 0.1^{\circ} \mathrm{C}, \mathrm{N}=4\right.$ atria, 5 trials $)$. 
In heart muscle, stimulation of opioid ( $\mu$, $\kappa$, and $\delta$ ) or muscarinic $\left(\mathrm{M}_{2}\right)$ receptors may mediate a reduction in cardiac contractility (16-19), a result that can also be obtained by activating the $\beta_{3}$-adrenoceptor. This effect involves the nitric oxide synthase pathway $(20,21)$. In spite of these possibilities, our results showed that neither the opioid nor the muscarinic or adrenergic receptors seem to participate in the inotropic effects of AEx because no changes were observed in the atrial contractile response after the atrium had been treated with opioid, muscarinic or adrenergic antagonists.

It is well known that in cardiac muscle the higher the stimulation rate, the stronger the atrial forces. The mechanism underlying this process is an enhanced $\mathrm{Ca}^{2+}$ membrane influx (10). In contrast, however, when AEx was added to the bath, the Bowditch positive staircase phenomenon disappeared and furthermore during the stimulation overdrive the atrial force remained $16 \%$ below the control amplitude value. This huge change strongly suggests that the AEx could be acting on the guinea pig atrium by blocking the membrane L-type $\mathrm{Ca}^{2+}$ channels.

In the spontaneously beating atria, AEx produced a concentration-dependent negative chronotropic effect. It has been well established that the slow diastolic depolarization, which can be observed between two successive action potentials of pacemaker myocardial cells (e.g., sinoatrial cells), is a phenomenon that, according to Lipsius et al. (22), involves several kinds of membrane ionic currents such as: 1) a slow inward $\mathrm{Na}^{+}$ current, $I_{f}$, the so-called 'funny current' that is induced by cell hyperpolarization, 2) a temporal decrease of the outward $\mathrm{K}^{+}$current due to a time-dependent decay of the membrane $\mathrm{K}^{+}$conductance, 3) a low background $\mathrm{K}^{+}$outward current, 4) an inward $\mathrm{Na}^{+} / \mathrm{Ca}^{2+}$ exchange current, and 5) an inward T-type and L-type $\mathrm{Ca}^{2+}$ current. The individual contribution of these currents to the pacemaker functioning is, however, controversial. To decrease the atrial rate, as in fact the $A$. carambola extract does, one or even many of these currents should be altered. It seems less probable that $I_{f}$ could be involved with the extract mechanism of action because intracellular recordings of the cardiac cell transmembrane potential showed a slight depolarization $(10 \mathrm{mV})$ when $500 \mu \mathrm{g} / \mathrm{ml}$ of crude extract was added to the extracellular medium (data not shown). Thus, the effect of $A$. carambola does not seem to be related to an acetylcholine-like mechanism because, if this were the case, an increase of the outward $\mathrm{K}^{+}$current would occur, leading to cellular hyperpolarization. Apart from the electrical change, this mechanism also appears to be an implausible hypothesis since blockade of the muscarinic receptors did not interfere with the effects of the extract. Supporting this assumption, we observed that the AEx increased the electrocardiographic QT interval in isolated hearts (data not shown). This result suggests that the extract may, in fact, block some of the membrane $\mathrm{K}^{+}$channels, an effect opposite to that of acetylcholine.

The $\mathrm{Na}^{+} / \mathrm{Ca}^{2+}$ exchange can either extrude $\mathrm{Ca}^{2+}$ (as an inward $\mathrm{I}_{\mathrm{Na} / \mathrm{Ca}}$ current) or bring $\mathrm{Ca}^{2+}$ into the cell (as an outward $\mathrm{I}_{\mathrm{Na} / \mathrm{Ca}}$ current) (23). The inward current of the $\mathrm{Na}^{+} /$ $\mathrm{Ca}^{2+}$ exchanger is an important event for generating the pacemaker action potential. Unfortunately, we have no data to conclude precisely about the importance of such current on the mechanism of action of $A$. carambola.

Isoproterenol, a $\beta_{1-2}$ adrenergic agonist, was able to antagonize the negative effect of the AEx on atrial chronotropism. This suggests that the inward $\mathrm{Ca}^{2+}$ current through the T-type and L-type channels could be an important target for the myocardial changes promoted by $A$. carambola, especially those related to the atrial pacemaker mechanism. This hypothesis is supported by the fact that the extract strongly inhibits the Bowditch positive staircase, a phenomenon that is 
known to be dependent on the cellular $\mathrm{Ca}^{2+}$ influx through the L-type membrane $\mathrm{Ca}^{2+}$ channels (24). The rightward displacement of the $\mathrm{CaCl}_{2}$ produced by the $\mathrm{AEx}$ also suggests that the calcium inward current is reduced by the action of the extract on the myocardium. The $\mathrm{Ca}^{2+}$ inward current is a crucial element for the excitation-contraction coupling due to its pivotal importance for triggering $\mathrm{Ca}^{2+}$ release from the sarcoplasmic reticulum, the so-called $\mathrm{Ca}^{2+}$-induced $\mathrm{Ca}^{2+}$ release (25).

According to the Napralet ${ }^{\mathrm{TM}}$ data base (Natural Products Alert, College of Pharmacy, University of Illinois, Chicago, IL, USA), many substances have been isolated from and identified in A. carambola. Among them there are four flavonoids (chrysanthemum, cyanin, isoquercitrin, rutin) isolated from flowers, and several terpenoids (sesquiterpenes, monoterpenes, and one triterpene, i.e., lupeol) isolated from fruit and bark. Gentisic acid and some alkaloids were isolated from the leaves of the plant. Unfortunately, there is no report dealing with the effect of these substances on heart tissue. Some papers have reported that carambola fruits are rich in oxalates. However, in 1.0 $\mathrm{mg} / \mathrm{ml}$ of leaf carambola AEx we could only find $21 \mu \mathrm{g} / \mathrm{ml}$ of oxalic acid. At this low concentration neither oxalic acid nor sodium oxalate were able to change atrial contractility (data not shown), suggesting that such agents cannot be the main depressant compounds present in the carambola leaf extracts.

The present study, which was carried out in the left and right guinea pig atria, demonstrated that the $A$. carambola AEx is an agent that strongly depresses the heart rate and the myocardial contractile force. Although the active compound has not been identified, its action on the L-type $\mathrm{Ca}^{2+}$ channels is important to explain the mechanism of action of this plant on the mammalian atrial myocardium.

\section{Acknowledgments}

The authors thank Professor José Maria Barbosa Filho (LTF/UFPB, Paraíba, Brazil) and Mr. Raimundo Nonato Silva Filho for their assistance in improving this paper.

\section{References}

1. Oliveira VPV, Cavalcanti FS, Bezerra CLF \& Pinto JL (1989). Plantas medicinais: considerações ecológicas e uso popular. Salusvita, 8: 49-58.

2. Pio-Correa M (1931). Dicionário de Plantas Úteis do Brasil. Ministério da Agricultura, Brasília, DF, Brasil.

3. Muir CK \& Lam CK (1980). Depressant action of Averrhoa carambola. Medical Journal of Malaysia, 34: 279-280.

4. Martha RCD, Poubel J, Ferreira LCL, Lima RS, Borrás MR, Costa PRC \& Roland IA (2000). Atividade hipoglicêmica de Averrhoa carambola L. usada em Manaus como antidiabético. NewsLab, 38: $142-148$.

5. Padmawinata K \& Hoyaranda $E$ (1980). The effect of the juice of Averrhoa carambola fruit and the aqueous extract of Persia americana leaves on rat blood pressure. 4th Asian Symposium on Medicinal Plants and Spices, Bangkok, Thailand, 159 (Abstract).

6. Neto MM, Costa JA, Garcia-Cairasco N, Netto JC, Nakagawa B \& Dantas M (2003). Intoxication by star fruit (Averrhoa carambola) in 32 uremic patients: treatment and outcome. Nephrology, Dialysis, Transplantation, 18: 120-125.

7. Tse K-C, Yip P-S, Lam M-F, Choy B-Y, Li F-K, Lui S-L, Lo W-K, Chan
T-M \& Lai K-N (2003). Star fruit intoxication in uremic patients: case series and review of the literature. Internal Medicine Journal, 33 : 314-316.

8. Neto MM, Robl F \& Netto JC (1998). Intoxication by star fruit (Averrhoa carambola) in six dialysis patients. Nephrology, Dialysis, Transplantation, 13: 570-572.

9. Chang J-M, Hwang S-J, Kuo H-T, Tsai J-C, Guh JY, Chen H-C, Tsai J-H \& Lai Y-H (2000). Fatal outcome after ingestion of star fruit (Averrhoa carambola) in uremic patients. American Journal of Kidney Diseases, 35: 189-193.

10. Chang CT, Chen YC, Fang JT \& Huang CC (2002). Star fruit (Averrhoa carambola) intoxication: an important cause of consciousness disturbance in patients with renal failure. Renal Failure, 24: 379-382

11. Cecchini AL, Fontana ACK, Beleboni RO, Pizzo AB, Santos $W F$, Thomazini JA, Neto MM \& Coutinho-Netto J (1999). Purification and biochemical characterization of a convulsant neurotoxin from the star fruit (Averrhoa carambola): specific neurotransmitter release on rat cerebral cortex synaptosomes. Presented at the XIV Annual Meeting of the Federação de Sociedades de Biologia 
Experimental, Caxambu, MG, Brazil, August 25-28, Abstract 12.193.

12. Domínguez XA (1973). Métodos de Investigación Fitoquímica. Editorial Limusa, México City, México.

13. Dorigo P, Gaion RM, Bergamin M, Giacometti A, Valentini E \& Moragno I (1990). Comparison between the cardiac effects induced by muzolimine and furosemide in guinea-pig atria. Cardiovascular Drugs and Therapy, 4: 1477-1486.

14. Nayler WG \& Merrillees NCR (1971). Cellular exchange of calcium. In: Harris P \& Opie LH (Editors), Calcium and the Heart. Academic Press, London and New York.

15. Rassi IE \& Damas MJ (1983). Método colorimétrico para determinação de oxalúria. Revista Brasileira de Patologia Clínica, 19: 171174.

16. Wong TM \& Shan J (2001). Modulation of sympathetic actions on the heart by opioid receptor stimulation. Journal of Biomedical Science, 8: 299-306.

17. Micol JA \& Laorden ML (1994). Effects of $\mu$-, $\delta$ - and $\kappa$-agonists on isolated right atria of the rat. Neuropeptides, 26: 365-370.

18. Giessler C, Dhein S, Pönicke K \& Brodde OE (1999). Muscarinic receptors in the failing human heart. European Journal of Pharmacology, 375: 197-202.

19. Shi H, Yang B, Xu D, Wang H \& Wang Z (2003). Electrophysiological characterization of cardiac muscarinic acetylcholine receptors: different subtypes mediate different $\mathrm{K}^{+}$currents. Cellular Physiology and Biochemistry, 13: 59-74

20. Kitamura T, Onishi K, Dohi K, Okinaka T, Isaka N \& Nakano T (2000). The negative inotropic effect of $\beta_{3}$-adrenoceptor stimulation in the beating guinea pig heart. Journal of Cardiovascular Pharmacology, 35: 786-790.

21. Gauthier C, Leblais V, Kobzik L, Trochu J-N, Khandoudi N, Bril A Ballingand J-L \& Le Marec $H$ (1998). The negative inotropic effect of $\beta_{3}$-adrenoceptor stimulation is mediated by activation of a nitric oxide synthase pathway in human ventricle. Journal of Clinical Investigation, 102: 1377-1384.

22. Lipsius SL, Hüser J \& Blatter LA (2001). Intracellular $\mathrm{Ca}^{2+}$ release sparks atrial pacemaker activity. News in Physiological Sciences, 16: 101-106.

23. Bers DM (2002). Cardiac excitation-contraction coupling. Nature, 415: $198-204$

24. Grossman A \& Furchgott RF (1964). The effects of frequency of stimulation and calcium concentration on ${ }^{45} \mathrm{Ca}$ exchange and contractility in the isolated guinea pig auricle. Journal of Pharmacology and Experimental Therapeutics, 143: 120-130.

25. Lamb GD (2000). Excitation-contraction coupling in skeletal muscle: comparisons with cardiac muscle. Clinical and Experimental Pharmacology and Physiology, 27: 216-224 